\title{
53. GEOTECHNICAL PROPERTIES OF INTRASLOPE BASIN SEDIMENTS, GULF OF MEXICO, DEEP SEA DRILLING PROJECT LEG 96, SITE 6191
}

\author{
William Bryant, Texas A\&M University \\ Andreas Wetzel, Universität Tübingen \\ and \\ William Sweet, Mineral Management Service ${ }^{2}$
}

\begin{abstract}
Geotechnical examination of $180 \mathrm{~m}$ of core recovered in Pigmy Basin at Site 619 in the Gulf of Mexico indicates that excess pore-water pressures are present in the lower section of the hole. Shear strength-vertical effective stress relationships and consolidation testing (oedometer) indicate that the sediments are normally consolidated in the upper $30 \mathrm{~m}$ and underconsolidated below. The presence of gas within the pore waters greatly affected the measurements of shear strength, water content, and porosity in the interval between 80 and $160 \mathrm{~m}$ sub-bottom.
\end{abstract}

\section{INTRODUCTION}

Two intraslope basins were drilled during Leg 96 at Sites 618 (Orca Basin) and 619 (Pigmy Basin). Site 618 was drilled in Orca Basin, an anoxic basin on the northwest continental slope in the Gulf of Mexico. No physical properties were measured on the sediments recovered from Site 618, as these sediments contained large amounts of methane in bubble gas phase.

Site 619 is located in Pigmy Basin, a northeast-southwest trending intraslope basin approximately $206 \mathrm{~km}$ south of the Louisiana shoreline (see Site 619 chapter, this volume). The basin has a flat seafloor at a water depth of approximately $2260 \mathrm{~m}$ and steeply sloping walls formed by the salt diapirs that rise approximately $700 \mathrm{~m}$ above the basin floor. The basin fill shows a number of seismic sequences, each starting with a transparent or semitransparent zone, overlain by a zone with discontinuous, more or less parallel reflectors and then by distinct, parallel continuous reflectors. This sequence is repeated numerous times with varying thicknesses. Unconformities are often apparent at the lower boundary of each seismic sequence, possibly indicating differential uplift of the adjacent salt diapirs between the time of deposition of each sequence (Bouma, Stelting, et al., this volume). Varying lithologies within the seismic sequences referred to above should be reflected in the physical properties, such as water content, porosity (void ratio), undrained shear strength, and consolidation characteristics of Site 619 sediments.

The principal results of the drilling at Site 619 show that the late Pleistocene basin fill consists primarily of pelagic and hemipelagic sediments with only minor interruptions by localized mass-movement (such as slump)

\footnotetext{
${ }^{1}$ Bouma, A. H., Coleman, J. M., Meyer, A. W., et al., Init. Repts. DSDP, 96: Washington (U.S. Govt. Printing Office).

2 Addresses: (Bryant) Department of Oceanography, Texas A\&M University, College Station, TX 77843; (Wetzel) Geologisches Institut der Universität, Sigwartstrasse 10, D7400 Tübingen, West Germany; (Sweet) Mineral Management Service, P.O. Box 7944, Metairie, LA 77010 .
}

deposits (see Site 619 chapter, this volume). In the deposits laid down during glacial times, a few thin coarsegrained turbidite sequences are present. Fine-grained mud turbidites are common throughout the section cored. A well-preserved and rather complete biostratigraphic section of the Wisconsin was penetrated that includes Ericson's Zones Z, Y, and X (Ericson and Wollin, 1968; Kohl, this volume). Computed sedimentation rates were $41.7 \mathrm{~cm} / 1000 \mathrm{yr}$. for the Holocene (Zone Z, $5 \mathrm{~m}$ thick), $194.5 \mathrm{~cm} / 1000 \mathrm{yr}$. for the late Wisconsin glacial (Zone Y, $142 \mathrm{~m}$ thick), and at least $23.8 \mathrm{~cm} / 1000 \mathrm{yr}$. for the Wisconsin interstadial (Zone X, $10 \mathrm{~m}$ thick) (Site 619 chapter, this volume). The maximum rate of accumulation in Pigmy Basin is a half order of magnitude lower than that of the middle Mississippi Fan sediments (Wetzel and Kohl, this volume).

The purpose of this study was to ascertain the nature of the physical properties, especially the degree of consolidation and amount of excess pore water, of an intraslope basin which contains a minimum of mass-movement deposits such as slumps. Since the basin is completely enclosed, the deposited sediments have little opportunity of being removed by erosional processes. Thus, the sediment within this basin should represent one of the most complete sections of hemipelagic slope sediments within the Gulf of Mexico.

\section{PHYSICAL PROPERTIES: METHODS AND RESULTS}

\section{Shear Strength}

Shear strength was measured on board ship using both a hand-held torque watch and $12.5 \mathrm{~mm}$ by $12.5 \mathrm{~mm}$ vane and a Soil Test Torvane. Readings taken by these two devices at similar depths within the hole are almost identical.

Shear strength increased downward in the upper $50 \mathrm{~m}$ of cored section at Site 619 at a rate of approximately $1 \mathrm{kPa} / \mathrm{m}$; the rate of increase between 50 and $175 \mathrm{~m}$ subbottom was $0.6 \mathrm{kPa} / \mathrm{m}$ (Fig. 1). The lower gradient for 


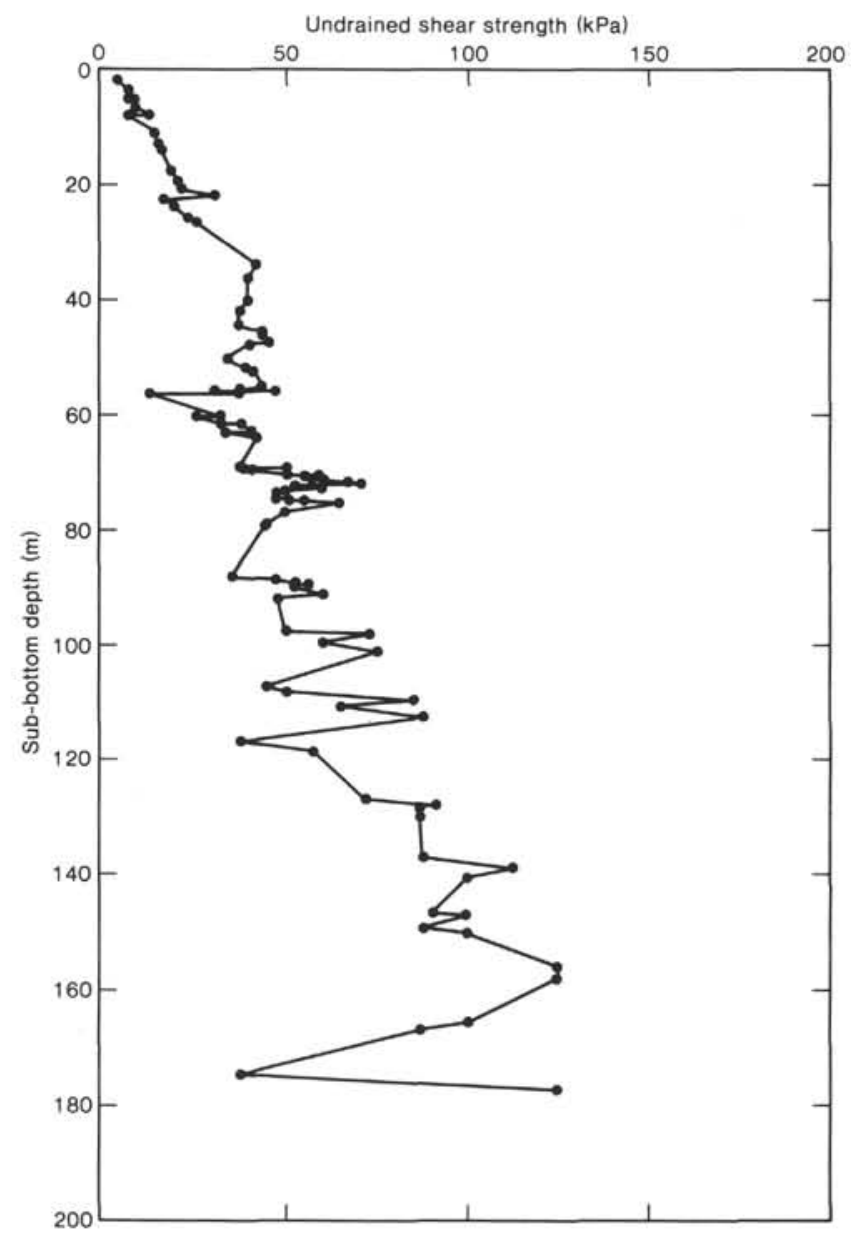

Figure 1. Undrained shear strength as a function of depth at Site 619.

the deeper sediments may be attributed in part to core disturbance created by the expansion of gas within the pore waters resulting from release of hydrostatic pressure during the core retrieval process. As a comparison, Figure 2 is an undrained shear strength versus depth profile of samples measured from Site 624, drilled on the lower portions of the Mississippi Fan in the overbank deposits adjacent to the major Mississippi Fan channel (see Site 624 chapter, this volume). The majority of sediments at this site were fine- and coarse-grained turbidites. The increase in shear strength in the upper $20 \mathrm{~m}$ of both Figures 1 and 2 are similar. The rate of increase in shear strength with depth is much higher in the Site 624 sediments than in Site 619, particularly in the 60 to $130 \mathrm{~m}$ interval. The strength profile for Site 624 is a more typical marine profile, where strength steadily increases with depth, than that of Site 619.

Figure 3 is a plot of depth versus the ratio of undrained shear strength $\left(C_{\mathrm{u}}\right)$ to the vertical effective stress $\left(\bar{\sigma}_{\mathrm{o}}\right)$. Skempton (1970) has suggested that $C_{\mathrm{u}} / \bar{\sigma}_{\mathrm{o}}$ ratios of 0.21 or less indicate that the sediment tested is underconsolidated (Bryant et al., this volume). Figure 3 shows that Site 619 sediments deeper than 10 to $15 \mathrm{~m}$ sub-bottom have $C_{\mathrm{u}} / \bar{\sigma}_{\mathrm{o}}$ ratios less than 0.21 and are, therefore, assumed to be underconsolidated. The underconsolidated nature of these sediments is attributed to several fac-

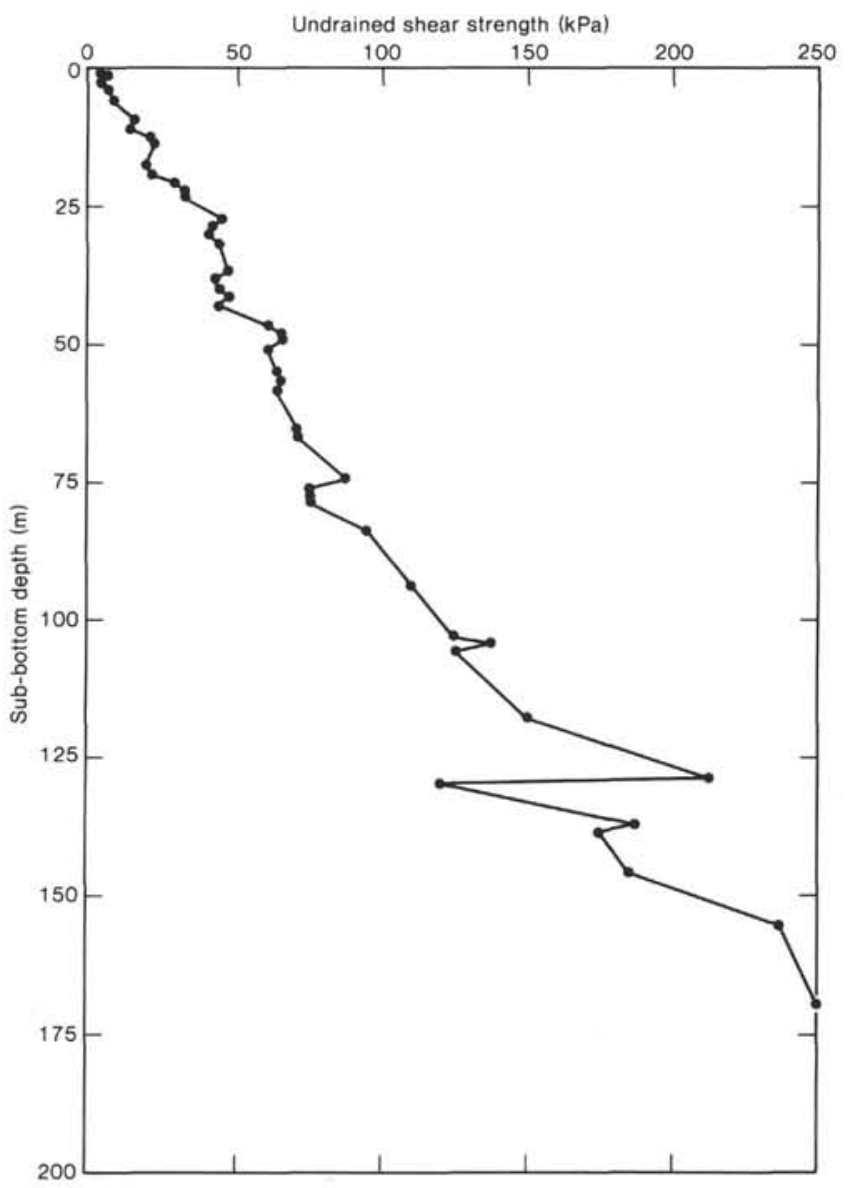

Figure 2. Undrained shear strength as a function of depth at Site 624, Mississippi Fan.

tors: the presence of gas in the pore waters, core disturbance, relatively high rates of sediment accumulation, and very low permeability (see below).

\section{Water Content and Porosity}

Water content is defined as the weight of the water divided by the weight of the solids. Water content was determined by weighing a given volume of sediment, drying at $100^{\circ} \mathrm{C}$ for $24 \mathrm{hr}$., and reweighing to determine weight loss.

At Site 619, water content decreased steadily from a maximum value of $116 \%$ at the seafloor to a minimum value of $21 \%$ at $175 \mathrm{~m}$ sub-bottom depth (Fig. 4). Data points from 90 to $140 \mathrm{~m}$ sub-bottom that show an increase in water content with depth, deviating from the general trend depicted by the dashed line on Figure 4, were made on gassy sediments.

The porosity of the seafloor sediments is approximately $75 \%$ (Fig. 5). The porosity decreases sharply to a depth of $50 \mathrm{~m}$ at a rate of $0.40 \%$ per meter. Below that depth, the sediment porosity decreases at a slower rate, $0.136 \%$ per meter. The slower rate of porosity decrease in the deeper section results in part from the gassy nature of these sediments; the dashed line in Figure 5 illustrates what would be the normal (i.e., gas free) trend of porosity with depth. 


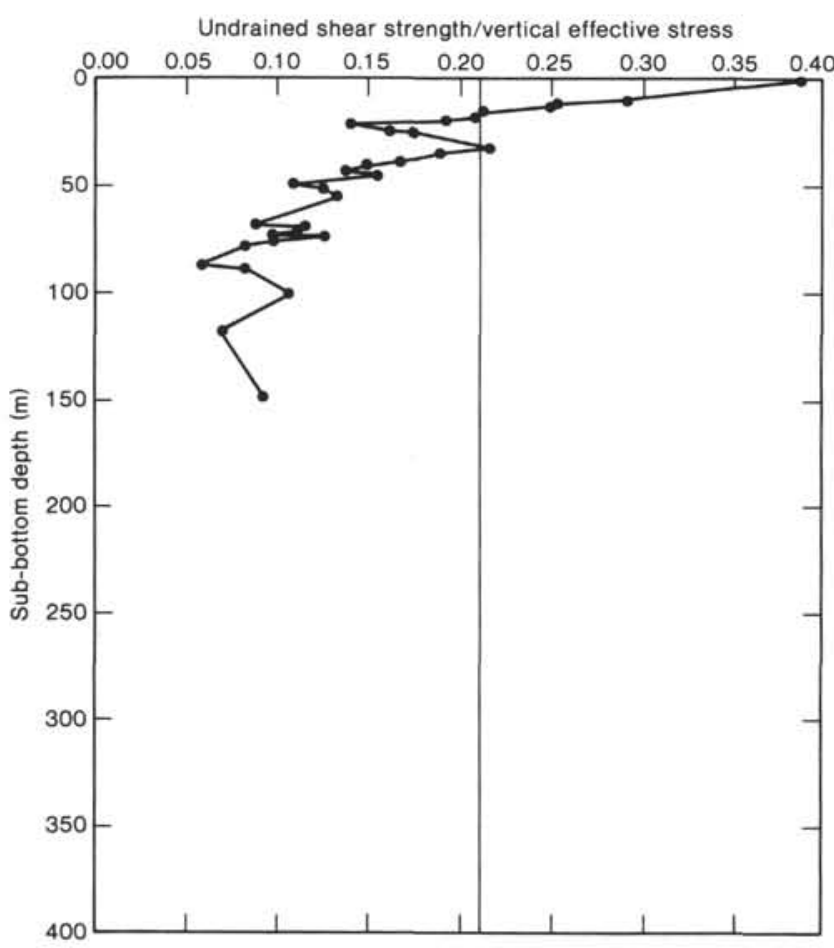

Figure 3. The ratio of undrained shear strength $\left(C_{u}\right)$ to vertical effective stress $\left(\bar{\sigma}_{\mathrm{o}}\right)$ as a function of depth below the seafloor at Site 619 . The values to the left of the vertical line at 0.21 are considered to represent underconsolidated sediments (Skempton, 1970).

\section{Consolidation}

The general conditions of consolidation, factors that affect the consolidation process, and consolidation test methods are discussed in Bryant et al. (this volume). Nine consolidation tests were run on Site 619 sediments; these samples were located at $8.48,13.38,23.16,34.26,55.14$, $70.08,99.00,147.05$, and $175.95 \mathrm{~m}$ sub-bottom depth. The results of these tests are summarized in Table 1 . Because the true value of the preconsolidation stress, the largest effective stress the samples have ever been subjected to, is very difficult to determine, a range of these values is listed. The minimum value is the value at the intersection of the extended virgin curve and a horizontal line through the original or highest void ratio; the maximum value of stress listed was derived from an examination of the rebound characteristics (Bryant et al., this volume). The average value of the preconsolidation stress listed in the table is the midpoint between these minimum and maximum values.

For average values of the preconsolidation stress, the sediments at Site 619 are normally consolidated in the upper $10 \mathrm{~m}$ and underconsolidated, except at the $34.26-\mathrm{m}$ level, below $10 \mathrm{~m}$ sub-bottom. Consolidation characteristics as determined from the maximum values of preconsolidation stress indicate that the majority of the cored section is overconsolidated. The former interpretation is preferred because it does not conflict with the shear strength/vertical effective stress relationship already established even though that relationship is somewhat affected by the presence of gas. For four of the nine levels tested, $13.38,23.16,55.14$, and $175.95 \mathrm{~m}$, the maxi-

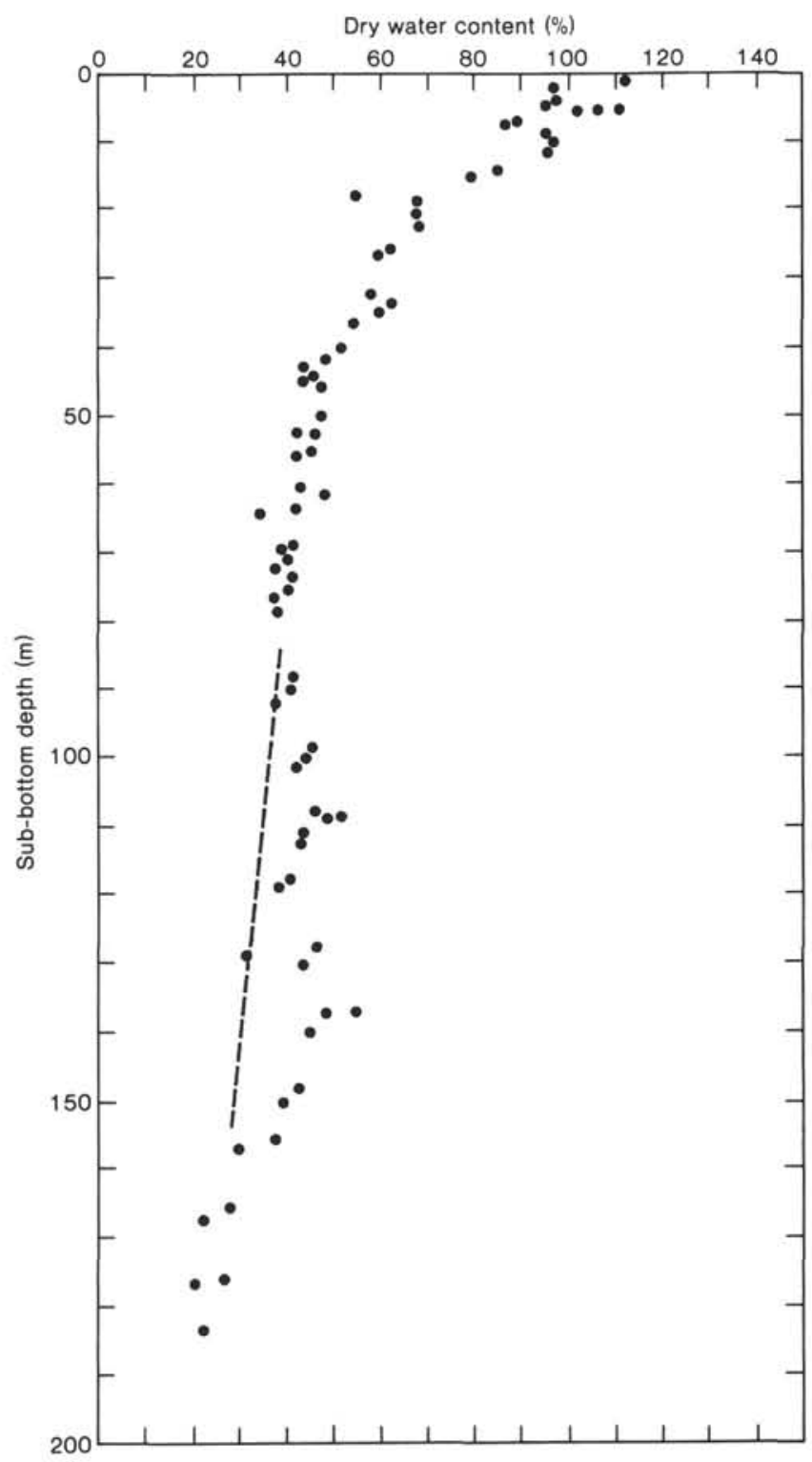

Figure 4. Variation of water content versus depth, Site 619. Dashed line represents normal gas-free trend.

mum value of the preconsolidation stress is less than the projected vertical effective stress under hydrostatic conditions, indicating that the sediments at those levels are definitely underconsolidated.

It is our opinion that the true value of the preconsolidation stress most likely falls somewhere on the high side of the average value, which would make most of the sediments underconsolidated to normally consolidated. Examination of the void ratio-log of vertical effective stress diagram for five sediment samples measured from Site 619 shows that sediments with high void ratios have a curve indicative of fairly undisturbed sediment (Fig. 6). It would appear that the consolidation tests are less affected by whatever is affecting the shear strength of the sediment, whether it be disturbance from coring or from the effects of gas expansion. The consolidation tests were run under back-pressured conditions. Back-pressuring renders the sediments saturated, thus removing part of 


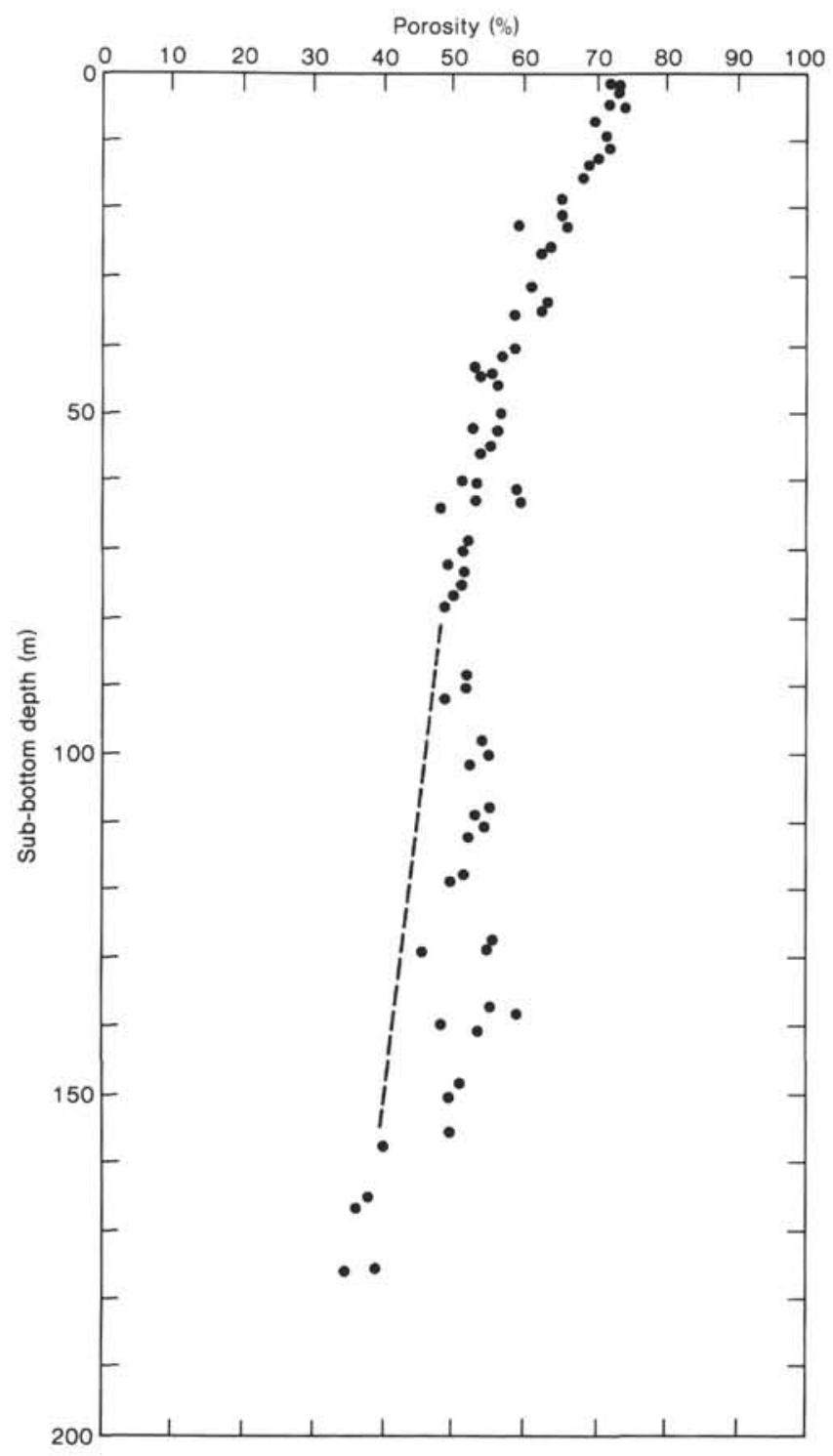

Figure 5. Variation of porosity versus depth, Site 619. Dashed line represents normal gas-free trend.

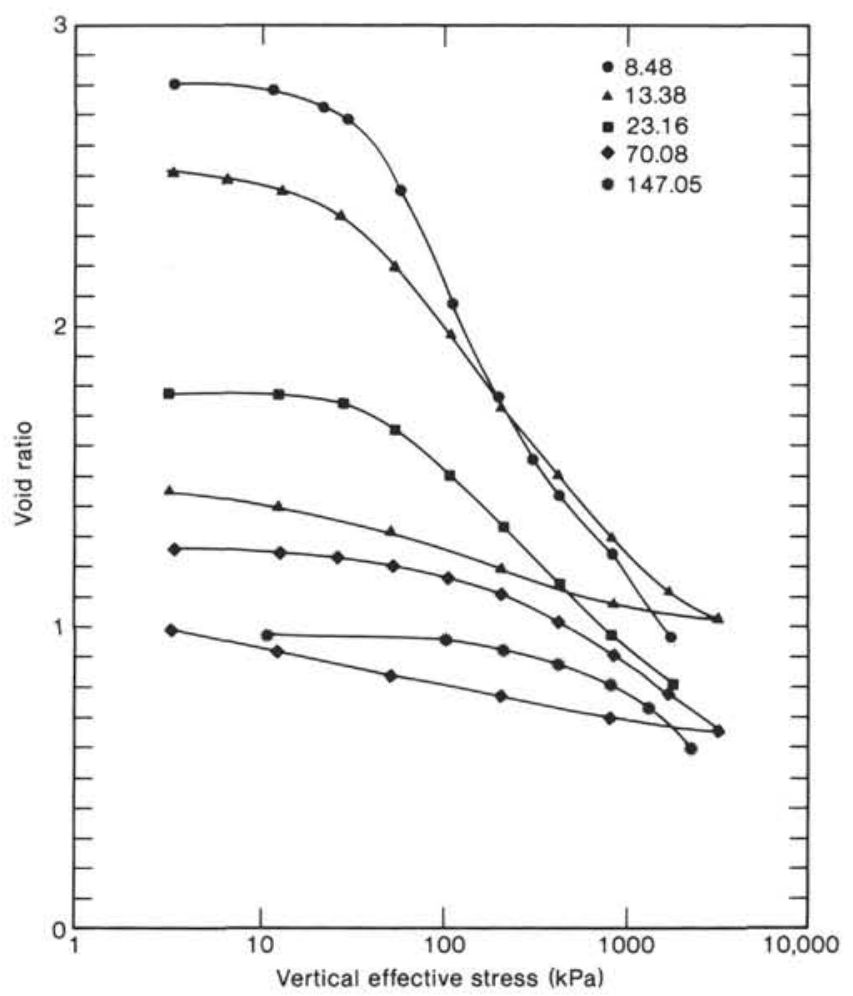

Figure 6. Void ratio-vertical effective stress diagrams for sediment samples from $8.48,13.38,23.16,70.08$, and $147.05 \mathrm{~m}$ sub-bottom depth at Site 619.

the effect of gas. This may be a partial explanation for the difference in results observed between the shear strength and effective stress relationship and oedometer testing to determine the consolidation characteristics.

Figure 7 graphically summarizes the results of the consolidation (oedometer) tests. This figure displays the vertical effective stress (under hydrostatic conditions), the preconsolidation stress at three levels (minimum, average, and maximum values), the range of excess pore-water pressures, and in situ vertical effective stress levels. The line labeled " $\mathrm{B}$ " in Figure 7 is the most probable location of the in situ vertical effective stress level at Site 619. The most probable values of excess pore-water pressure that exist at the site are those resulting from the dif-

Table 1. Conditions of consolidation and excess pore-water pressures for sediments at Site 619.

\begin{tabular}{|c|c|c|c|c|c|c|c|c|c|}
\hline $\begin{array}{l}\text { Sub- } \\
\text { bottom } \\
\text { depth } \\
\text { (m) }\end{array}$ & $\begin{array}{c}\text { Effective } \\
\text { overburden } \\
\text { stress, } \bar{\sigma}_{\mathrm{o}} \\
(\mathrm{kPa})\end{array}$ & $\begin{array}{c}\text { Minimum-average- } \\
\text { maximum } \\
\text { preconsolidation } \\
\text { stress, } \bar{\sigma}_{\mathrm{c}} \\
(\mathrm{kPa})\end{array}$ & $\begin{array}{c}\text { OCR for } \\
\text { average } \\
\text { and high } \\
\text { values of } \\
\bar{\sigma}_{\mathrm{c}}\end{array}$ & $\begin{array}{c}\text { Consolidation } \\
\text { characteristics }^{\mathrm{a}} \\
\text { (average-maximum) }\end{array}$ & $\begin{array}{c}\text { Minimum } \\
\text { pore-water } \\
\text { pressure } \\
(\mathrm{kPa})\end{array}$ & $\begin{array}{c}\text { Maximum } \\
\text { pore-water } \\
\text { pressure } \\
(\mathrm{kPa})\end{array}$ & $\begin{array}{c}\text { Liquid } \\
\text { limit } \\
W_{\mathrm{L}}\end{array}$ & $\begin{array}{c}\text { Plastic } \\
\text { limit } \\
W_{\mathrm{P}}\end{array}$ & $\begin{array}{c}\text { Plasticity } \\
\text { index } \\
I \\
\left(W_{\mathrm{L}}-W_{\mathrm{P}}\right)\end{array}$ \\
\hline 8.48 & 36 & $22-36-50$ & $1.00-1.38$ & $\mathrm{NC}-\mathrm{OC}$ & 0 & 0 & 105 & 38 & 66 \\
\hline 13.38 & 56 & $34-42-50$ & $0.75-0.89$ & UC-UC & 6 & 22 & $-\mathrm{b}$ & - & - \\
\hline 23.16 & 114 & $44-61-80$ & $0.54-0.70$ & HUC-UC & 34 & 70 & 83 & 31 & 52 \\
\hline 34.26 & 186 & $90-178-270$ & $0.96-1.45$ & $\mathrm{NC}-\mathrm{OC}$ & 0 & 99 & 85 & 34 & 51 \\
\hline 55.14 & 340 & $135-217-300$ & $0.64-0.88$ & HUC-UC & 40 & 205 & 67 & 27 & 41 \\
\hline 70.08 & 405 & $200-397-600$ & $0.82-1.23$ & UC-OC & 0 & 285 & - & - & - \\
\hline 99.00 & 698 & $320-558-800$ & $0.81-1.16$ & UC-OC & 0 & 369 & 72 & 24 & 48 \\
\hline 147.05 & 1040 & $400-850-1300$ & $0.81-1.25$ & UC-OC & 0 & 190 & 64 & 24 & 40 \\
\hline 175.95 & 1215 & $200-612-1025$ & $0.50-0.84$ & HUC-UC & 190 & 603 & 84 & 25 & 59 \\
\hline
\end{tabular}

${ }_{\mathrm{b}}^{\mathrm{a}} \mathrm{NC}=$ normally consolidated, $\mathrm{OC}=$ overconsolidated, $\mathrm{UC}=$ underconsolidated, and $\mathrm{HUC}=$ highly underconsolidated.

b - means not determined. 


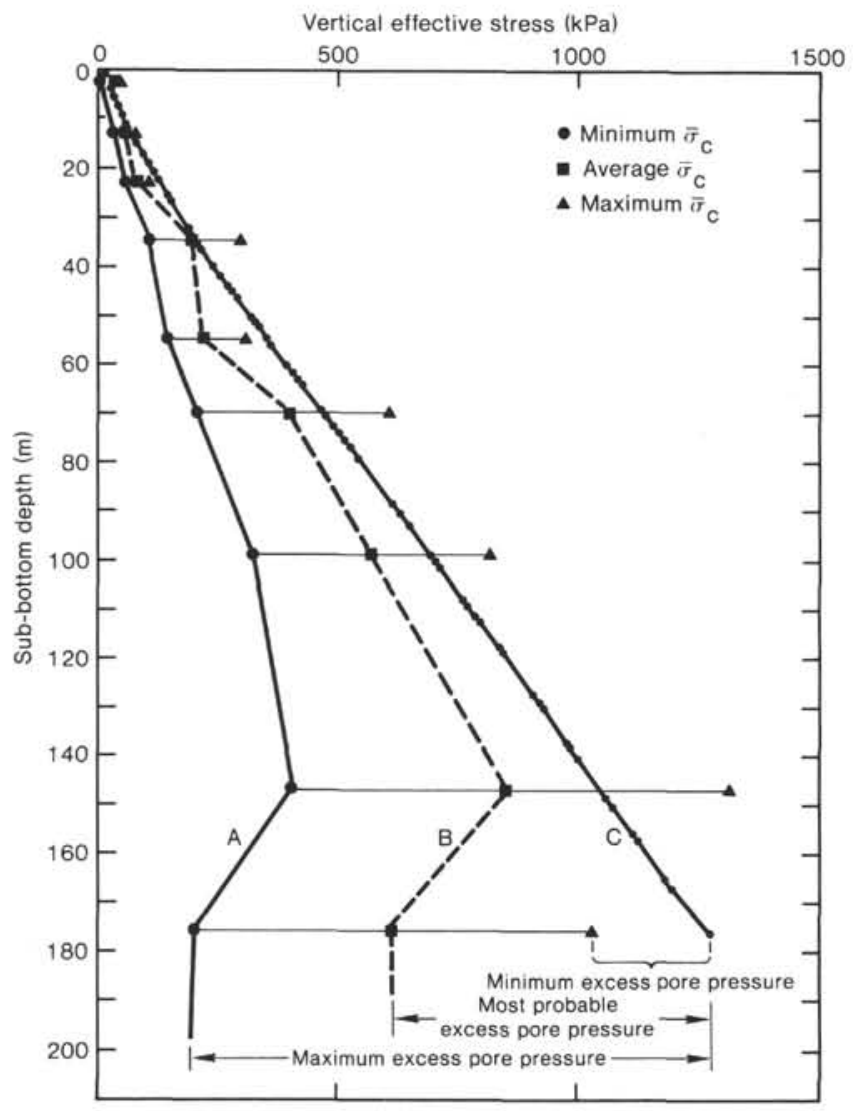

Figure 7. Plot of the vertical effective stress assuming hydrostatic conditions as a function of depth at Site 619. Line A is the minimum preconsolidation pressure, line $\mathrm{B}$ is the average preconsolidation pressure, and line $\mathrm{C}$ is the vertical effective stress. The amount of excess pore-water pressure can be calculated for the three conditions of the preconsolidation pressure (minimum, maximum, and average) by subtracting the amount of line $A$ from line $C$ for the maximum value of pore pressure and line $B$ from line $C$ for the average pore pressure value. Line B represents the most probable in situ vertical effect stress level at Site 619.

ference between the average preconsolidation stress (line B) and the vertical effective stress under hydrostatic conditions (line C). These values are also listed in Table 1.

\section{Permeability}

The four factors that primarily control the consolidation process include depth of burial, grain size, porosity, and permeability. Permeability of Site 619 sediments was computed by the use of a laboratory consolidation test (oedometer) on the basis of the equation of consolidation developed by Terzaghi (1943) (see Bryant et al., this volume, for further details).

The permeabilities of the Site 619 sediments range from $3 \times 10^{-6} \mathrm{~cm} / \mathrm{s}\left(3 \times 10^{-3}\right.$ darcys $)$ for near-seafloor sediments to $5 \times 10^{-10} \mathrm{~cm} / \mathrm{s}\left(3 \times 10^{-7}\right.$ darcys $)$ for sediments at the $178-\mathrm{m}$ sub-bottom level. Figure 8 shows the relationship between the depth of burial and the permeability of a sample from the $13.38-\mathrm{m}$ level in the Pigmy Basin core. Permeability was determined on that sample at various degrees of void ratio. The various levels of void ratio were translated to depth of burial by the use of Figure 7. The result is a theoretical permeabil- ity-depth relationship (Fig. 8) which agrees with the calculated values from the consolidation testing at the eight other levels within the hole.

\section{CONCLUSIONS}

The presence of methane gas and the subsequent disturbance of the sediments caused by the expansion of that gas during core retrieval greatly affects the quality of sediments cored at Sites 618 and 619. At Site 618 the disturbance was so great that no physical properties were measured.

At Site 619 the major effect of gas appears to have been on the undrained shear-strength measurements. The shear-strength profile at Site 619 increases at a rate substantially lower than the more typical marine sediment rates measured at Site 624 on the Mississippi Fan, even though the rate of sediment accumulation at Site 624 was a half order of magnitude higher than at Site 619.

Examination of Site 619 consolidation test (oedometer) results indicates that the presence of gas did not affect the results of consolidation testing as much as it did the shear-strength measurements. The consolidation tests indicate that sediments below the 10 - $\mathrm{m}$ level are normally consolidated to underconsolidated; sediments near the seafloor are normally consolidated to overconsolidated. The degree of underconsolidation in the deeper section

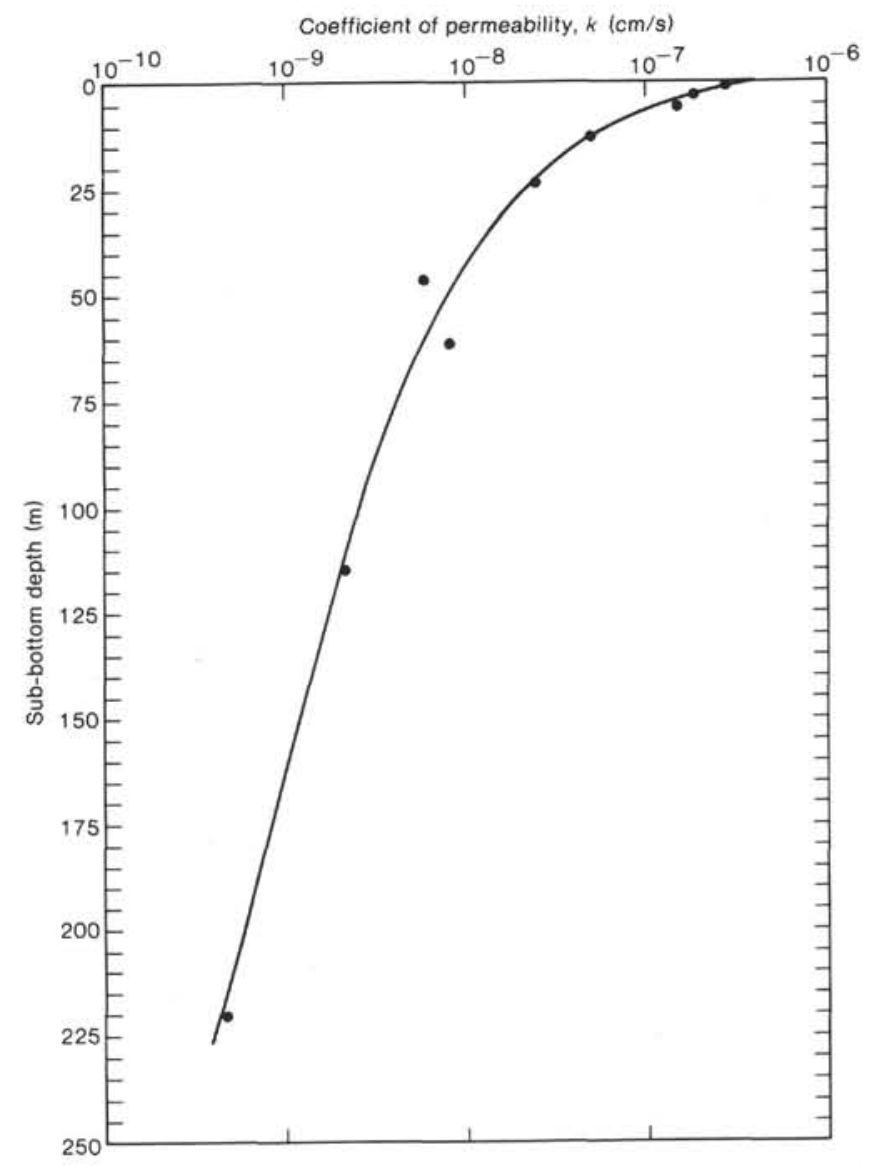

Figure 8. Variation of permeability (coefficient of permeability) with depth at Site 619 as determined from a sample taken at the 13.38-m level. 
is difficult to ascertain, but it appears that below a depth of $30 \mathrm{~m}$ the sediments are probably from 50 to $80 \%$ consolidated.

The permeability and coefficient of consolidation of Pigmy Basin sediments are similar to those of the clayey sediments of the Mississippi Fan (Bryant et al., this volume). Permeabilities at Site 619 range from $3 \times 10^{-6}$ to $5 \times 10^{-10} \mathrm{~cm} / \mathrm{s}$; the coefficient of consolidation averages $4 \times 10^{-4} \mathrm{~cm}^{2} / \mathrm{s}$.

The most significant conclusions drawn from the geotechnical investigation of Site 619 sediments are (1) that excess pore-water pressures are probably present within the sediments of Pigmy Basin below a depth of $30 \mathrm{~m}$; (2) that if Pigmy Basin sediments display excess porewater pressures while having some of the lowest rates of sediment accumulation in the Gulf of Mexico, then all the Gulf of Mexico fine-grained sediments below a certain depth also likely have excess pore-water pressure; and (3) that the results of the consolidation tests (oedometer) appear to be affected by the presence of gas to a lesser extent than the results of the other physical properties tests.

\section{ACKNOWLEDGMENTS}

The authors wish to thank A. Meyer, P. Valent, and E. Taylor for their help and review of this manuscript. Sandy Drews is thanked for the preparation of the many revisions of this manuscript.

\section{REFERENCES}

Ericson, D. B., and Wollin, G., 1968. Pleistocene climates and chronology in deep-sea sediments. Science, 162:1227-1234.

Skempton, A. W., 1970. The consolidation of clays by gravitational compaction. Quart. J. Geol. Soc. London, 125:373-411.

Terzaghi, 1943. Theoretical Soil Mechanics: New York (Wiley).

Date of Initial Receipt: 11 February 1985

Date of Acceptance: 8 November 1985 